\title{
Implementasi Pendekatan Konstruktivisme melalui Model Pembelajaran CLIS (Children Learning In Science) dan Pengaruhnya terhadap Aktivitas Belajar dan Kemampuan Kognitif Siswa
}

\author{
Dewi Ratnasaria), Sukarmin ${ }^{\text {b) }}$, Y. Radiyono ${ }^{\text {c) }}$ \\ Program Studi Pendidikan Fisika, Universitas Sebelas Maret, \\ Jl. Ir. Sutami 36 A, Surakarta
}

Email: a)dewi_ratnasari@student.uns.ac.id, ${ }^{\text {b)}}$ sukarmin67@staff.uns.ac.id, ${ }^{c}$ yradiyono@staff.uns.ac.id

\begin{abstract}
The aim of this research is to implementation constructivism approach through CLIS (Children Learning In Science) learning model and its immpact toward students' learning activities and cognitive ability. This action resesarch was analyzed by descriptive quantitative. Research subjects is students in 11th grade in the academic year 2013/2014 in the static fluid material. The data of this research from observation technique when learning process and cognitive test in the end of learning. Students' learning activities in this research consist of visual activities, oral activities dan writing activities that described into many indicators, whereas cognitive test uses multiple choice instrument that has been properness analyzed. Based on research result and data analysis get result as follows: 1) The value of normalization in visual activities is 0,78 (high), oral activities is 0,31 (adequate), writing activities is 0,49 (adequate); 2) The increase of average achievement of students' cognitive ability based on gain normalization is 0,32 (adequate) after learning with constructivism approach through CLIS (Children Learning In Science) model.
\end{abstract}

Keywords: learning activities, Children Learning In Science, cognitive ability.

\begin{abstract}
Abstrak
Penelitian ini bertujuan untuk mengimplemantasikan pendekatan konstruktivisme melalui model pembelajaran CLIS (Children Learning In Science) dan pengaruhnya terhadap aktivitas belajar dan kemampuan kognitif siswa. Penelitian tindakan ini dianalisis menggunakan deskriptif kuantitatif dengan subjek penelitian adalah siswa kelas XI pada tahun ajaran 2013/2014 pada materi fluida statis. Data penelitian diperoleh dari hasil observasi selama proses pembelajaran dan hasil tes kognitif pada akhir pembelajaran. Aktivitas belajar siswa pada penelitian ini terdiri dari visual activities, oral activities dan writing activities yang dijabarkan menjadi beberapa indikator, sedangkan tes kognitif siswa menggunakan instrumen pilihan ganda yang telah dianalisis kelayakannya. Berdasarkan hasil penelitian dan analisis data diperoleh hasil sebagai berikut: 1) Nilai gain ternormalisasi pada visual activities sebesar 0,78 (tinggi); oral activities sebesar 0,31 (sedang); writing activities sebesar 0,49 (sedang); 2) Peningkatan rata-rata nilai ketuntasan kemampuan kognitif siswa berdasarkan nilai gain ternormalisasi sebesar 0,32 (sedang) setelah pembelajaran dengan mengimplementasi pendekatan konstruktivisme melalui model CLIS (Children Learning In Science).
\end{abstract}

Kata-kata Kunci: Aktivitas belajar, Children Learning In Science, kemampuan kognitif. 


\section{PENDAHULUAN}

Usaha pemerintah menciptakan sumber daya manusia berkualitas tinggi melalui pendidikan yang sesuai dengan fungsi dan tujuan pendidikan Nasional pada Undang-undang Republik Indonesia nomor 20 tahun 2003 Bab II Pasal 3 tentang sistem pendidikan nasional yakni mengembangkan kemampuan dan membentuk watak serta peradaban bangsa yang bermartabat dalam rangka mencerdaskan kehidupan bangsa, bertujuan untuk berkembangnya potensi peserta didik agar menjadi manusia yang beriman dan bertakwa kepada Tuhan Yang Maha Esa, berakhlak mulia, sehat, berilmu, cakap, kreatif, mandiri, dan menjadi warga Negara yang demokratis serta bertanggung jawab.

Pendidikan adalah usaha sadar untuk menumbuhkembangkan potensi Sumber Daya Manusia (SDM) melalui kegiatan pengajaran. Muslich (2007:194) menyatakan bahwa terdapat dua konsep kependidikan yang berkaitan satu dengan yang lainnya, yaitu belajar (learning) dan pembelajaran (instruction). Konsep belajar berakar pada pihak peserta didik dan konsep pembelajaran berakar pada pihak pendidik.

Terkait pernyataan tersebut, belajar menjadi proses yang sangat penting untuk mencapai tujuan pendidikan nasional. Perubahan-perubahan yang terjadi dalam proses belajar menjadikan aspek penentu keberhasilan pada proses belajar itu sendiri. Proses belajar dipengaruhi beberapa faktor. Slameto (2010: 54) menyatakan bahwa faktor-faktor yang mempengaruhi proses belajar dapat digolongkan menjadi dua yaitu faktor intern dan faktor ekstern. Faktor intern adalah faktor yang ada dalam diri individu yang sedang belajar. Sedangkan faktor ekstern adalah faktor yang ada di luar diri individu yang sedang belajar.

Berdasarkan observasi dan wawancara yang telah dilakukan ditemukan beberapa masalah yang muncul dalam proses pembelajaran yang berdampak pada masih rendahnya hasil belajar siswa, hal ini ditunjukan dengan masih banyaknya siswa yang belum mencapai nilai batas ketuntasan yang telah ditetapkan sekolah yaitu 75. Menurut guru yang bersangkutan, salah satu penyebab beberapa masalah tersebut adalah masih seringnya penggunaan metode ceramah dalam kegiatan pembelajaran. Hal ini dikarenakan keterbatasan waktu dan keterbatasan pengetahuan guru tentang model pembelajaran inovatif.

Tindakan yang dilakukan dalam upaya meningkatkan kemampuan kognitif dan aktivitas belajar siswa ditempuh dengan penerapan pendekatan konstruktivisme. Menurut Kunandar (2006: 301) menyatakan bahwa pendekatan konstruktivisme adalah landasan berfikir pembelajaran kontekstual yang menyatakan bahwa pengetahuan dibangun manusia sedikit demi sedikit yang hasilnya diperluas melalui konteks yang terbatas (sempit) dan tidak terjadi secara instan. Oleh sebab itu, pendekatan ini menekankan pada keterlibatan siswa dalam proses belajar aktif, sehingga pengetahuan dibentuk oleh siswa secara aktif bukan hanya diterima secara pasif dari guru. Salah satu model pembelajaran yang berorientasi pada pendekatan konstruktivisme adalah model Children Learning In Science (CLIS).

Model CLIS merupakan model pembelajaran yang berusaha mengembangkan ide atau gagasan siswa tentang suatu masalah tertentu dalam pembelajaran serta merekonstruksi ide atau gagasan berdasarkan hasil pengamatan atau percobaan. Model CLIS merupakan salah satu model yang strateginya berorientasi pada konstruktivisme (Wali, 2008).

Berdasarkan hasil penelitian yang dilakukan oleh tim CLIS di Leeds University dalam jurnal Internasional yang ditulis Driver (1988) menyatakan bahwa penelitian yang dilakukan oleh tim CLIS bertanggungjawab terhadap banyak penelitian penting yang terkait dengan gagasan anak terhadap Sains. Berdasarkan hasil penelitian ini, penerapan model CLIS dapat meningkatkan aktivitas belajar siswa. Model CLIS mendorong siswa untuk mampu membangun pengetahuan dalam pikirannya sendiri sehingga konsep akan lebih tertanam dan tidak sekedar hafalan.

\section{METODE PENELITIAN}

Penelitian ini merupakan penelitian tindakan yang hasilnya dianalisis secara deskriptif kuantitatif untuk menggambarkan aktivitas belajar dan kemampuan kognitif siswa setelah implementasi pendekatan konstruktivisme melalui model CLIS (Children Learning In Science). Aktivitas belajar siswa yang diamati dalam penelitian ini terdiri dari visual activities, oral activities dan writing 
activities dengan menggunakan pedoman dari Sardiman (2010: 101). Penjabaran setiap aspek aktivitas belajar dapat dilihat pada TABEL 1 .

TABEL 1. Indikator aktivitas belajar siswa

\begin{tabular}{ll}
\hline Aktivitas belajar & Indikator \\
\hline Visual activities & Siswa memperhatikan penjelasan guru/teman \\
& Siswa membaca buku Fisika/LKS \\
& Siswa bertanya kepada guru jika ada hal yang kurang jelas. \\
Oral activities & Siswa menjawab pertanyaan yang diajukan guru tanpa \\
& ditunjuk. \\
& Siswa memberikan tanggapan/sanggahan atas pendapat teman. \\
& Siswa memberikan pendapat/saran untuk memecahkan masalah \\
& dalam diskusi kelompok \\
& Siswa menulis hasil pemecahan masalah dalam diskusi. \\
& Siswa mencatat materi yang disampaikan oleh guru \\
\hline
\end{tabular}

Data aktivitas belajar diperoleh dengan menggunakan lembar observasi yang dilakukan sebelum tindakan dan setelah tindakan. Hasil yang diperoleh kemudian dihitung dengan menggunakan nilai gain ternormalisasi. Data lain yaitu kemampuan kognitif siswa yang diperoleh dengan menggunakan dengan instrumen pilihan ganda yang terlebih dahulu diuji kelayakannya.

Teknik analisis data pada penelitian ini menggunakan perhitungan gain ternomalisasi yang diperoleh dari selisih skor akhir dan skor awal. Gain ternormalisasi dapat dihitung dengan mengukur gain skor siswa sebelum dan setelah mengikuti kegiatan pembelajaran dengan menggunakan pendekatan konstruktivisme dengan model CLIS. Persamaan gain ternormalisasi menurut Meltzer (2002:1260) sebagai berikut:

$$
\langle g\rangle=\frac{\left\langle S_{f}\right\rangle-\left\langle S_{i}\right\rangle}{\left\langle S_{m}\right\rangle-\left\langle S_{i}\right\rangle}
$$

Keterangan :

$\langle g\rangle=$

$\left\langle S_{f}\right\rangle=$ gain ternormalisasi

$\left\langle S_{i}\right\rangle=$

$\left\langle S_{m}\right\rangle=$ skor maksimal

Kriteria gain ternormalisasi menurut Meltzer (2002:1260) dapat dilihat pada TABEL 2.

TABEL 2. Kriteria gain ternormalisasi

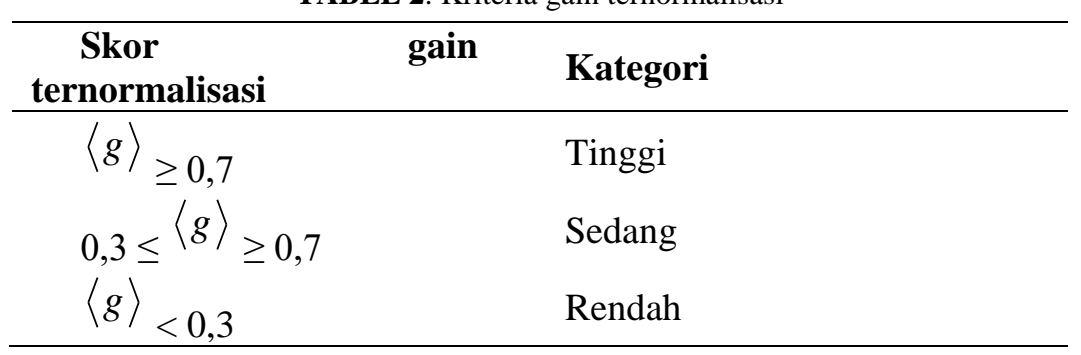




\section{HASIL DAN PEMBAHASAN}

Penelitian ini diawali dengan kegiatan pencarian data-data yang berkaitan dengan subjek penelitian dengan tujuan untuk mengetahui gambaran awal keadaan kelas. Adapun kegiatan yang dilaksanakan meliputi wawancara guru, observasi kelas serta kajian dokumen. Dari hasil kajian dokumen dan wawancara dengan guru Fisika diketahui bahwa hasil belajar siswa masih rendah. Hal ini ditunjukkan dengan hasil ulangan pada bab sebelumnya yakni bab Gelombang dan Bunyi hanya $36.84 \%$ yang dinyatakan tuntas dan rata-rata skor siswa sebesar 68,42. Berdasarkan hasil observasi awal diketahui bahwa aktivitas belajar siswa dalam proses pembelajaran masih rendah. Rendahnya aktivitas belajar siswa saat proses pembelajaran ini muncul karena proses pembelajaran yang dilakukan masih bersifat Teacher Centered Learning (TCL). Hasil analisis aktivitas belajar siswa sebelum implementasi model CLIS dan setelah implementasi CLIS dapat dilihat pada TABEL 3.

TABEL 3. Hasil analisis aktivitas belajar siswa

\begin{tabular}{lllc}
\hline \multirow{2}{*}{ No } & Indikator & \multicolumn{2}{l}{ Persentase ketercapaian (\%) } \\
\cline { 3 - 4 } & Sebelum & Sesudah \\
\hline 1. & $\begin{array}{l}\text { Visual activities } \\
\text { Siswa memperhatikan penjelasan guru/teman }\end{array}$ & 78.95 & 94.44 \\
& $\begin{array}{l}\text { Siswa membaca buku Fisika/LKS } \\
\text { Oral activities } \\
\text { Siswa bertanya kepada guru jika ada hal yang } \\
\text { kurang jelas. }\end{array}$ & 84.21 & 97.42 \\
& $\begin{array}{l}\text { Siswa menjawab pertanyaan guru tanpa } \\
\text { ditunjuk. }\end{array}$ & 42.11 & 32.45 \\
& $\begin{array}{l}\text { Siswa berani memberikan } \\
\text { tanggapan/sanggahan atas pendapat teman. }\end{array}$ & 15.79 & 75.86 \\
& $\begin{array}{l}\text { Siswa memberikan pendapat/saran untuk } \\
\text { memecahkan masalah dalam diskusi }\end{array}$ & 0 & 27.78 \\
kelompok. & $\begin{array}{l}\text { Writing activities } \\
\text { Siswa menulis hasil pemecahan masalah dalam } \\
\text { diskusi. }\end{array}$ & 0 & 32.31 \\
$\begin{array}{l}\text { Siswa mencatat materi yang disampaikan oleh } \\
\text { guru. }\end{array}$ & 84.21 & 40.5 \\
\hline
\end{tabular}

TABEL 3 menunjukkan hasil observasi aktivitas belajar siswa sebelum dan sesudah implementasi pendekatan konstruktivisme melalui model CLIS. Indikator aktivitas belajar siswa yang diamati telah ditentukan seperti pada TABEL 1. Indikator tersebut digunakan sebagai pedoman dalam menilai aktivitas siswa selama proses pembelajaran menggunakan model CLIS. Berdasarkan hasil analisis aktivitas belajar siswa pada TABEL 3 dapat dilihat bahwa dominasi terbesar pada visual activities, hal ini menunjukkan bahwa siswa masih memiliki ketertarikan untuk mendengarkan penjelasan dari guru. Aktivitas terendah yakni pada oral activities yakni pada aktivitas kelompok. Rendahnya aktivitas ini karena siswa tidak dibiasakan untuk menemukan konsep pada kegiatan kelompok. Data lain pada penelitian ini yaitu kemampuan kognitif siswa yang diperoleh dari hasil tes pilihan ganda pada akhir pembelajaran fisika. Instrumen pilihan ganda yang digunakan terlebih dahulu diuji kelayakannya. Data hasil uji kelayakan instrumen tes kemampuan kognitif dapat dilihat pada TABEL 4.

TABEL 4. Hasil uji kelayakan instrumen

\begin{tabular}{llllllllll}
\hline \multirow{2}{*}{ Reliabilitas } & \multicolumn{3}{c}{ Validitas } & \multicolumn{4}{c}{ Daya pembeda } & \multicolumn{3}{c}{ Taraf kesukaran } \\
\cline { 2 - 10 } & Valid & Invallid & Jelek & Cukup & Baik & $\begin{array}{l}\text { Baik } \\
\text { sekali }\end{array}$ & Sukar & Sedang & Mudah \\
\hline $\begin{array}{l}0,778 \\
\text { (Tinggi) }\end{array}$ & 23 & 7 & 8 & 15 & 7 & 0 & 10 & 7 & 13 \\
\hline
\end{tabular}


Soal yang belum memenuhi syarat sebagai soal yang baik dan layak tidak digunakan dalam penelitian ini, sehingga hanya 20 item yang dinyatakan layak dan sesuai dengan indikator yang akan diukur. Indikator yang diukur pada instrumen pilihan ganda disesuaikan dengan silabus dan RPP yang telah disusun guru dan peneliti. Berdasarkan hasil tes diperoleh rata-rata nilai siswa setelah implementasi pendekatan konstruktivisme melalui model CLIS sebesar 78,42.

Berdasarkan hasil observasi dan hasil tes sebelum dan sesudah implementasi pendekatan konstruktivisme melalui model CLIS dapat diketahui peningkatan ketercapaian dengan menggunakan gain ternormalisasi. Pedoman perhitungannya gain ternormalisasi menggunakan rumus (1). Hasil perbandingan sebelum dan sesudah implementasi pendekatan konstruktivisme melalui model CLIS serta nilai gain ternormalisasi dapat dilihat pada TABEL 5.

TABEL 5. Hasil analisis aktivitas belajar siswa dan kemampuan kognitif sebelum dan sesudah implementasi CLIS

\begin{tabular}{lllll}
\hline Aspek & Sebelum & Sesudah & Gain ternormalisasi & Kategori \\
\hline Visual activities & 81.58 & 95.93 & 0.78 & Tinggi \\
\hline Oral activities & 17.11 & 42.11 & 0.31 & Sedang \\
\hline Writing activities & 42.11 & 70.25 & 0.49 & Sedang \\
\hline Kemampuan kognitif & 68.42 & 78.42 & 0.32 & Sedang \\
\hline
\end{tabular}

Berdasarkan TABEL 5, dapat dilihat bahwa nilai gain ternormalisasi terbesar pada aspek visual activities. Nilai gain ternormalisasi menunjukkan seberapa besar efektivitasnya untuk meningkatkan aspek tertentu, sehingga semakin tinggi nilai gain ternormalisasinya menunjukkan model CLIS semakin efektif untuk meningkatkan aspek yang diukur. Untuk memperjelas perbedaan setiap aspek sebelum dan sesudah implementasi pendekatan konstruktivisme melalui model CLIS dapat dilihat pada GAMBAR 1.

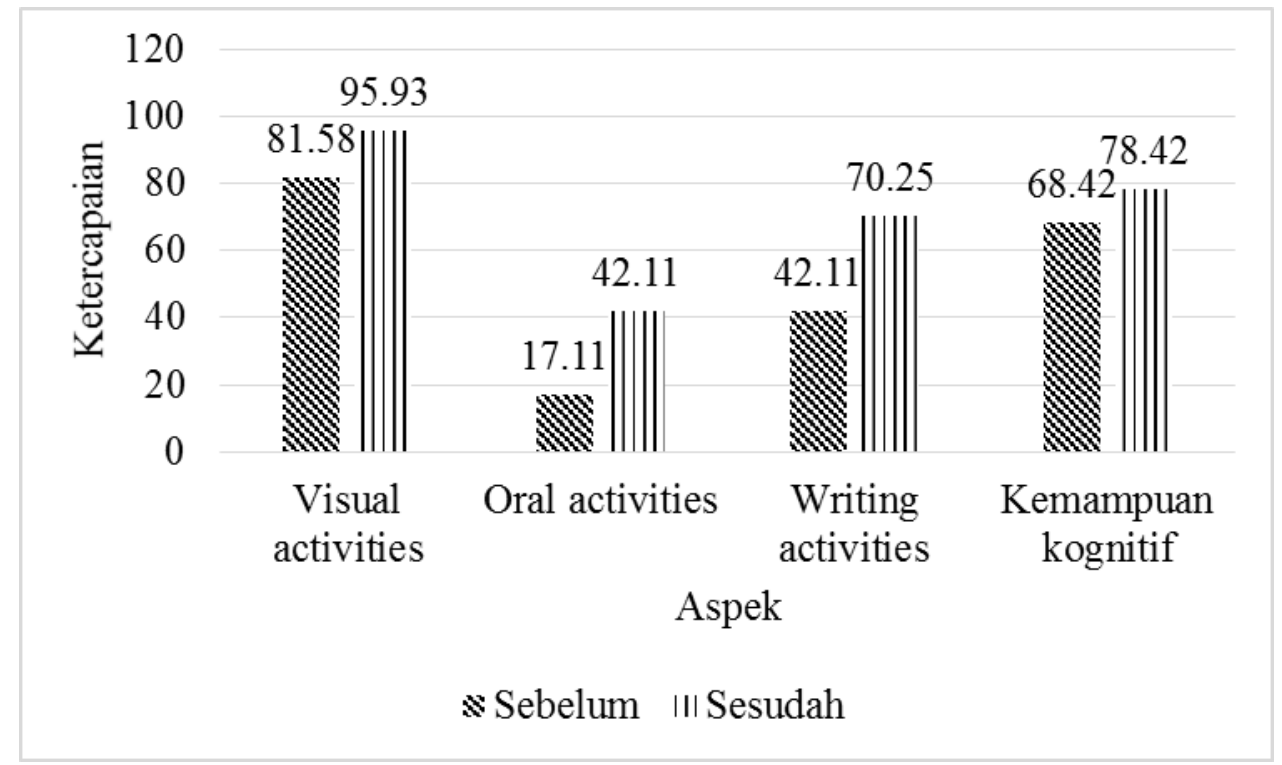

GAMBAR 1. Grafik perbandingan setiap aspek sebelum dan sesudah implementasi pendekatan konstruktivisme melalui model CLIS.

Berdasarkan GAMBAR 1 terlihat jelas peningkatan setiap aspek sebelum dan sesudah implementasi pendekatan konstruktivisme melalui model CLIS. Model CLIS merupakan model pembelajaran yang strateginya berorientasi pada konstruktivisme (Cosgrove dan Osborne, 1985: 101). Sedangkan Dahar (1989: 160) menyatakan bahwa model konstruktivisme dalam pengajaran memiliki prinsip dasar yaitu siswa memperoleh banyak pengetahuan di luar sekolah dan proses pendidikan di sekolah seharusnya memperhatikan hal tersebut dan menunjang proses secara alamiah. Model CLIS memiliki lima tahap yang dirangkum oleh Wali (2008), yakni tahap pengenalan (orientation), tahap pemunculan gagasan (elicitation of ideas), tahap penyusunan ulang gagasan 
(restucting of ideas), tahap penerapan gaagsan (application of ideas) dan tahap pemantapan gagasan (review change in ideas). Melalui kelilma tahap dalam model CLIS ini siswa dituntut untuk lebih aktif di kelas dan mampu untuk mengkonstruksi gagasan atau konsep secara mandiri.

Peningkatan aktivitas belajar siswa karena implementasi model CLIS ini diungkapkan oleh Driver (1989) menyatakan bahwa reaksi siswa terhadap lingkungan belajar yang terbuka, partisipasi siswa melalui belajar model CLIS lebih aktif dibandingkan dengan pembelajaran konvensional. Hal senada juga diungkapkan oleh Yulaikah (2010) yang menyatakan bahwa model Children Learning In Science (CLIS) membuat siswa aktif dalam kegiatan karena siswa diberi kesempatan untuk menyampaikan pendapatnya, selain itu CLIS mendorong siswa untuk mengungkapakan ide-idenya dan mendorong siswa untuk berpikir kritis, sehingga model CLIS ini sangat sesuai untuk meningkatkan aktivitas belajar siswa. Peningkatan aktivitas belajar siswa berdampak pula pada peningkatan kemampuan kognitif yang dimiliki siswa.

Menurut Handayani (2004), model pembelajaran CLIS menjadi salah satu alternatif yang dapat digunakan untuk meningkatkan keterampilan berpikir rasional siswa. Hal ini menegaskan bahwa model CLIS tidak hanya mampu meningkatkan aktivitas belajar siswa tetapi juga mampu meningkatkan kemampuan kognitif siswa. Kemampuan kognitif siswa masih menjadi salah satu parameter penentu keberhasilan suatu proses belajar mengajar.

Pada prinsipnya belajar adalah berbuat untuk mengubah tingkah laku. Dalam proses belajar, aktivitas peserta didik merupakan hal yang sangat penting dan perlu diperhatikan oleh guru agar proses belajar mendapat hasil yang optimal. Sardiman (2010: 97) mengungkapkn bahwa tanpa ada aktivitas, proses belajar tidak mungkin terjadi, sehingga orang yang dikatakan belajar apabila aktif dalam kegiatan belajar mengajar.

\section{SIMPULAN}

Berdasarkan hasil penelitian dan analisis data diperoleh hasil sebagai berikut: 1) Nilai gain ternormalisasi pada visual activities sebesar 0,78 (tinggi); oral activities sebesar 0,31 (sedang); writing activities sebesar 0,49 (sedang); 2) Peningkatan rata-rata nilai ketuntasan kemampuan kognitif siswa berdasarkan nilai gain ternormalisasi sebesar 0,32 (sedang) setelah pembelajaran dengan mengimplementasi pendekatan konstruktivisme melalui model CLIS (Children Learning In Science). Hasil penelitian ini diharapkan mampu menjadi acuan bagi penelitian-penelitian lain yang sejenis, sehingga mampu meningkatkan kualitas pembelajaran sains terutama pada pembelajaran fisika. Selain itu, penelitian ini diharapkan mampu menjadi masukan bagi perkembangan pendidikan di Indonesia.

\section{UCAPAN TERIMAKASIH}

Penulis mengucapkan terimakasih kepada seluruh pihak yang telah membantu terselesainya artikel ini.

\section{REFERENSI}

Cosgrove, M. and Osborne, R. 1985 'Lesson Frameworks for Changing Children's Ideas. In: Learning in Science: The implications of children's science, Osborne R. and Freyberg P (Eds). Auckland, Heinemann, pp. 101-111.

Dahar, R.W. "Teori-Teori Belajar Fisika” (Erlangga, Jakarta, 1996)

Driver, R, 1988 'Changing conceptions', Journal of Research in Education, vol 3, pp. 161-96.

Driver, R., Guesne, E., and Tiberghien A. "Children's Ideas and The Learning of Science" ( Open University Press, Philadhelpia, 1985)

Handayani, S., Nurmawati, Rahmiazasi, L. 2004 'Pengembanganmodel pembelajaran children learning in science meningkatkan keterampilan berpikir rasional', Jurnal Pendidikan, vol.5 pp. $37-47$ 
Kunandar. "Guru Profesional Implementasi Kurikulum Satuan Pendidikan" (PT Raja Grafindo Persada, Jakarta, 2007), pp. 301

Meltzer, D. E. 2002 'The relationship Between Mathematics Preparation and Conceptual Learning Gains in Physic: A Possible 'Hidden variable' in Diagnostic Pretest Score', American Journal of Physics, vol 70, pp. 1259-1268.

Muslich, M. "KTSP Pembelajaran Berbasis Kompetensi dan Kontekstual” ( Bumi Aksara, Jakarta, 2007), pp. 194

Sardiman A.M. "Interaksi dan Motivasi Belajar Mengajar" (Rajawali Press, Jakarta, 2010) pp. 101102.

Slameto. "Belajar dan Faktor-Faktor yang Mempengaruhi" (Rineka Cipta, Jakarta, 2010), pp. 54

Wali, M. 2008 Model-model Pembelajaran Inovatif. Tidak diterbitkan

Yulaikah, E. 2010. Pembelajaran Fisika Dengan Pendekatan Konstruktivisme Melalui Metode Children Learning In Science (CLIS) Ditinjau dari Aktivitas Belajar Siswa Pada Sub Pokok Bahasan Pemantulan Cahaya di SMP Kelas VIII Tahun Ajaran 2009/2010. Skripsi Tidak Dipublikasikan. FKIP Universitas Sebelas Maret Surakarta 
